\title{
The Effect of Reproductive Health Education with Multimedia Video Learning on the Improvement of Fluor Albus Prevention Behavior Young Woman Pathologist
}

\author{
A. Ummu Saadah Mukhtar \\ Department of Midwifery, Graduate School, Hasanuddin University \\ Corresponding author email: andiummu1995@gmail.com \\ Budu \\ Department of Medical Sciences, Graduate School, Hasanuddin University \\ Email: budu062011@yahoo.com \\ Yusring Sanusi B \\ Center for Media Studies, Learning Resources and E-Learning Hasanuddin University, Indonesia \\ Email: jibril@yahoo.com
}

\author{
Nasruddin Andi Mappawere \\ Medical Faculty, Indonesian Muslim University \\ Email: nasrudin.nasrudin@umi.ac.id
}

\author{
Azniah \\ Nursing Department, Nani Hasanuddin College of Health Makassar \\ Email: azniahsyam @gmail.com
}

\begin{abstract}
Health education for adolescents is achieved properly, it requires effective and interactive media so that young women can easily understand and absorb the information provided properly. The population in this study were teenage girls in class XI Pesantren Al-Junaidiyah Biru, Pesantren Al-Ikhlas Ujung Bone and Islamic Boarding School Darussalam Pajalele Bone. Based on the determination of the number of samples, the sample in this study amounted to 18 respondents, in anticipation of dropping out of respondents from the study, the researchers set $20 \%$ so that the number of respondents was 22 respondents in each group (Using 1:1:1) so the sample in this study amounted to 66 people with purposive sampling technique. The results showed that there was an effect of reproductive health education with multimedia video learning on increasing knowledge of pathological fluor albus prevention in adolescent girls. The results showed that there was an effect of reproductive health education with multimedia video learning on improving the attitude of preventing pathological fluor albus (leucorrhoea) in adolescent girls. The results of the study indicate that there is an effect of reproductive health education with multimedia video learning on the improvement of behavior/prevention of pathological fluor albus (leucorrhoea) in adolescent girls.

Keywords---attitude, behavior/action, knowledge, multimedia video learning, reproductive health education.
\end{abstract}

\section{Introduction}

According to WHO, adolescence is a period when an individual develops from the time he first shows secondary sexual signs until he reaches sexual maturity, a period when individuals experience psychological development and

ISSN 2632-9433

Submitted: 27 November 2021 |Revised: 09 December 2021| Accepted: 18 January 2022 
identification patterns from childhood to adulthood and a period when there is a transition from dependence. full socio-economic conditions in a relatively more independent state (Santrock, 2003). Adolescence occurs when a person experiences changes in body structure from children to adults (Edunation, 2016).

Adolescence is defined as a period of transition from childhood to adulthood. Adolescence is a transitional period between childhood and adulthood, where a growth spurt occurs, secondary sex characteristics develop, fertility is achieved and psychological and cognitive changes occur. The growth process can take place well and it requires good and balanced nutrition so that it can grow and develop with normal reproductive abilities (Noorbaya et al., 2018).

In Indonesia as many as $90 \%$ of young women in Indonesia have the potential to experience fluor albus because Indonesia is an area with a tropical climate, so fungi, viruses, and bacteria are easy to grow, especially in the female area, causing many cases of flour albus in women in Indonesia (Azizah, 2015). Based on Indonesian statistics in 2012 from 43.3 million teenagers aged 15-24 years in Indonesia behaved unhealthily. Indonesian adolescent girls from 23 million people aged 15-24 years $83 \%$ have had sexual intercourse, which means that adolescents have the opportunity to experience PMS which is one of the causes of flour albus (Sari, 2015).

Based on the results of research conducted by Dewi (2015), on the effectiveness of health education using audiovisual media on personal hygiene (genital) behavior of young women in preventing flour albus, the p-value < is $0.00<0.05$, the results of this study indicate that health education using audiovisual media is effective on personal hygiene (genital) behavior of adolescent girls in preventing flour albus. Research conducted by Anggraeni (2014), on the Effectiveness of Reproductive Health Education with VLM (Video Learning Multimedia) Media on Knowledge and Attitudes of Health Cadres, obtained in the knowledge variable, the value of $Z=-6,346$ with a significance level of $0.000(p<0.05)$ and the variable attitude obtained a value of $Z=-6,326$ with a significance level of $0.000(p<0.05)$ it can be concluded that $\mathrm{H} 1$ is accepted, which means that reproductive health education using VLM media is considered effective (Kistan et al., 2020).

The results of research conducted at SMK Askhabul Kahfi Semarang showed that from 86 students, 74 (87\%) students had poor genital hygiene behavior, and as many as $62(72.1 \%)$ students experienced pathological flour albus (Anies, 2016). Another study conducted at SMA Negeri 6 Kendari showed that of $81(100 \%)$ respondents, as many as $62(76.5 \%)$ stated that they had experienced fluoralbus infection and $19(23.5 \%)$ respondents who had never had fluoralbus infection. Furthermore, the results of research conducted at SMA Negeri 8 Kendari showed that of the 72 respondents (100\%), there were 42 respondents $(58.3 \%)$ who were positive for fluor albus based on the questionnaire and 30 respondents $(41.7 \%)$ were negative for fluor albus (Pratiwi et al., 2016).

One of the reasons the researchers researched Pesantren Al-Junaidiyah Biru and Pesantren Al-Ikhlas Ujung Bone was because there was still a lack of education provided to students, this was reinforced by the researchers' initial observations by asking students that there was still minimal information obtained, especially regarding vaginal discharge or flour albus and most of the students also did not understand how to maintain personal hygiene when experiencing vaginal discharge and the researchers raised the title with the hope that after being given education through multimedia video learning, students could understand and understand how to maintain personal hygiene during vaginal discharge and at the same time the research location and The distance from where they live are close enough to make it easier for researchers to carry out research (Tesser, 1978; Zhang et al., 2020).

From the results of an initial survey conducted with 20 female students at the Blue Islamic Boarding School and the Al-Ikhlas Islamic Boarding School in Ujung Bone, gradually from all of the class XI teenage girls, the results of a direct interview survey were as many as 15 young girls had complained about the problem of flour albus or vaginal discharge, this was due to several factors including lack of knowledge about how to prevent Fluor albus or care about their reproductive organs (Homer et al., 2008; Van Gog \& Scheiter, 2010; Zhang et al., 2006).

\section{Research Methods}

The research was carried out with ethical approval recommendation number: 10127/UN4.14.1/TP.02.02/2021 with research locations in Madrasah Aliyah Al-Junaidiyah Biru Bone, Madrasah Aliyah Al-Ikhlas Ujung Bone and Madrasah Aliyah Darussalam Pajalele. This type of research is Quasy-experimental with Pre-test Post-Test Control Group Design. The population in this study were teenage girls in class XI Pesantren Al-Junaidiyah Biru, Pesantren Al-Ikhlas Ujung Bone and Islamic Boarding School Darussalam Pajalele Bone. This study did not involve class X because it has more dense hours and subjects so it is less possible to take lesson hours for this research activity. In addition, theoretically, class XI adolescents are in the middle adolescence stage, where at this stage adolescents can think abstractly, meaning that they can process information related to objects. Based on the determination of the number of samples, the sample in this study amounted to 18 respondents, in anticipation of dropping out of 
respondents from the study, the researchers set $20 \%$ so that the number of respondents was 22 respondents in each group (Using 1:1:1) so the sample in this study amounted to 66 people with Purposive Sampling technique.

\section{Result and Discussion}

The research was carried out with ethical approval recommendation number: 10127/UN4.14.1/TP.02.02/2021 with research locations in Madrasah Aliyah Al-Junaidiyah Biru Bone, Madrasah Aliyah Al-Ikhlas Ujung Bone and Madrasah Aliyah Darussalam Pajalele. This type of research is Quasy-experimental with Pre-test Post-Test Control Group Design. The population in this study were teenage girls in class XI Pesantren Al-Junaidiyah Biru, Pesantren Al-Ikhlas Ujung Bone and Islamic Boarding School Darussalam Pajalele Bone. This study did not involve class X because it has more dense hours and subjects so it is less possible to take lesson hours for this research activity. In addition, theoretically, class XI adolescents are in the middle adolescence stage, where at this stage adolescents can think abstractly, meaning that they can process information related to objects. Based on the determination of the number of samples, the sample in this study amounted to 18 respondents, in anticipation of dropping out of respondents from the study, the researchers set $20 \%$ so that the number of respondents was 22 respondents in each group (Using 1:1:1) so the sample in this study amounted to 66 people with Purposive Sampling technique.

Table 1

Analysis of the Manova Test for Reproductive Health Education With Multimedia Video Learning on the Improvement of Fluor Albus Prevention Behavior Young Woman Pathologist

\begin{tabular}{lll}
\hline & \multicolumn{1}{c}{ Effect } & Sig. \\
\cline { 2 - 3 } Method & Pillai's Trace & 0.001 \\
& Wilks' Lambda & 0.000 \\
& Hotelling's Trace & 0.000 \\
& Roy's Largest Root & 0.000 \\
\hline
\end{tabular}

* Manova Test

Based on the output of the Multivariate tests above, the significant values are seen in Pillai's Trace, Wilks' Lambda, Hotelling's Trace, and Roy's Largest Root contained in the effective method, and the overall significance value are $<0.05$. Through a significant value $<0.05$, then according to the decision-making criteria, $\mathrm{H} 0$ is rejected. That is, there is a difference in changes in knowledge, attitudes, and behavior/actions towards reproductive health education with multimedia video learning towards improving the behavior of preventing pathological fluor albus (leucorrhoea) in adolescent girls (Ananda et al., 2022; Lestari et al., 2021). Furthermore, to find out the difference between each variable individually, it can be seen in the Between-Subjects Effects table. The decision-making criteria are:

- If Sig. $<0.05$ then there is a change in each group of VLM+Education, VLM, and education on reproductive health education with multimedia video learning towards improving the behavior of preventing pathological fluor albus (leucorrhoea) in adolescent girls.

- If Sig.>0.05 then there was no change in each group of VLM+Education, VLM, and education on reproductive health education with multimedia video learning on the improvement of pathological fluor albus (leucorrhoea) prevention behavior in adolescent girls. The test output of Tests of Between-Subjects Effects is presented in the table below.

Through Online Learning there is an increased understanding of the creation of family planning midwifery care by $20 \%$ The results of this study show that students actively remain disciplined in carrying out learning activities online, namely by self-study after online learning and able to understand the lecture materials provided by the lecturers (Malterud, 2001; Gazmararian et al., 2003). The ability to learn independently is characteristic of online learning. In online learning, it is necessary to be skilled in learning independently (Ancheta et al., 2005; Lou et al., 2004; Chandra-Mouliet al., 2015). Because at the time of the learning process, students will search, find and conclude that have been studied independently. As Nyoman (2013), points out, self-learning is a process by which students are directly involved in identifying what needs to be learned to be the holder of control in the learning process. When learning independently, the element of motivation becomes so important for the development of success in the learning process. 


\section{Conclusion}

- The results showed that in the VLM + Education group, there was a dominant change in knowledge where there were 22 people. While the VLM group was 21 people and the education group was 8 people.

- The results showed that the dominant VLM + Education group experienced a change in attitude where there were 20 people. While the VLM group is 20 people and the education group is 10 people.

- The results showed that the dominant VLM + Education group experienced behavioral changes where there were 19 people. While the VLM group is 18 people and the education group is 5 people.

- The results showed that there was an effect of reproductive health education with multimedia video learning on increasing knowledge of pathological fluor albus prevention in adolescent girls with a $p$-value $=0.003$.

- The results showed that there was an effect of reproductive health education with multimedia video learning on the improvement of pathological fluor albus (leucorrhoea) prevention attitudes in adolescent girls with a pvalue $=0.001$.

- The results showed that there was an effect of reproductive health education with multimedia video learning on the improvement of behavior/prevention of pathological fluor albus (leucorrhoea) in adolescent girls with a $\mathrm{p}$-value $=0.009$.

\section{Acknowledgments}

It is recommended to the school that the educational video that researchers use can be used as a reference or can be developed so that students get media in the form of videos as educational material that it is important to maintain personal hygiene while experiencing vaginal discharge.

\section{References}

Ananda, A., Baso, Y. S., Hidayanty, H., Syarif, S., Aminuddin, A., \& Bahar, B. (2022). Providing education chronic energy deficiency (CED) uses web-based she smart to improve knowledge, attitudes, and practice in adolescent girls. International Journal of Health \& Medical Sciences, 5(1), 56-62. https://doi.org/10.21744/ijhms.v5n1.1833

Ancheta, R., Hynes, C., \& Shrier, L. A. (2005). Reproductive health education and sexual risk among high-risk female adolescents and young adults. Journal of pediatric and adolescent Gynecology, 18(2), 105-111. https://doi.org/10.1016/j.jpag.2005.01.005

Anggraeni, D. Y. (2014). Tuturan pada Anak Penyandang Tunagrahita Taraf Ringan, Sedang, dan Berat (Kajian Fonologi). Bahtera Sastra: Antologi Bahasa dan Sastra Indonesia, 1(2).

Azizah, N. (2015). Karakteristik remaja putri dengan kejadian keputihan di smk muhammadiyah kudus. Jurnal Ilmu Keperawatan dan Kebidanan, 6(1).

Chandra-Mouli, V., Svanemyr, J., Amin, A., Fogstad, H., Say, L., Girard, F., \& Temmerman, M. (2015). Twenty years after International Conference on Population and Development: where are we with adolescent sexual and reproductive health and rights? Journal of Adolescent Health, 56(1), S1-S6. https://doi.org/10.1016/j.jadohealth.2014.09.015

Dewi, A. P. (2015). Efektivitas pendidikan kesehatan menggunakan media audiovisual terhadap perilaku personal hygiene (genitalia) remaja putri dalam mencegah keputihan (Doctoral dissertation, Riau University).

Edunation. (2016). Remaja dan Klasifikasinya. Rineka Cipta, Jakarta.

Gazmararian, J. A., Williams, M. V., Peel, J., \& Baker, D. W. (2003). Health literacy and knowledge of chronic disease. Patient education and counseling, 51(3), 267-275. https://doi.org/10.1016/S0738-3991(02)00239-2

Homer, B. D., Plass, J. L., \& Blake, L. (2008). The effects of video on cognitive load and social presence in multimedia-learning. Computers in Human Behavior, 24(3), 786-797. https://doi.org/10.1016/j.chb.2007.02.009

Kistan, K., Malka, S., \& Musni, M. (2020). The relationship between knowledge, attitude, and readiness of academic community in Covid-19 spread prevention: Batari Toja Nursing Academy, Watampone. International Journal of Health \& Medical Sciences, 3(1), 72-78. https://doi.org/10.31295/ijhms.v3n1.155

Lestari, W. O. S. W., Syarif, S., Hidayanty, H., Aminuddin, A., \& Ramadany, S. (2021). Nutrition education with android-based application media to increase knowledge, attitudes, and behaviors of pregnant women about chronic energy deficiency (KEK). International Journal of Health \& Medical Sciences, 4(1), 15-22. https://doi.org/10.31295/ijhms.v4n1.440

Lou, C. H., Wang, B., Shen, Y., \& Gao, E. S. (2004). Effects of a community-based sex education and reproductive health service program on contraceptive use of unmarried youths in Shanghai. Journal of Adolescent Health, 34(5), 433-440. https://doi.org/10.1016/j.jadohealth.2003.07.020 
Malterud, K. (2001). The art and science of clinical knowledge: evidence beyond measures and numbers. The Lancet, 358(9279), 397-400. https://doi.org/10.1016/S0140-6736(01)05548-9

Noorbaya, S., Saidah, S., Ifansyah, N., \& Nazmy, M. R. (2018). Hubungan Status Gizi Dengan Ciri Seks Sekunder Pada Remaja Putri Usia 11-13 Tahun Di Sdn 003 Loa Janan Ulu Tahun 2017. Jurnal Kebidanan Mutiara Mahakam, 6(2), 21-30.

Nyoman. (2013). Memahami Perkembangan Fisik Remaja. Alphabeta, Bandung.

Pratiwi, T. M., Sabilu, Y., \& Fachlevy, A. F. (2016). Hubungan Pengetahuan, Stres, Penggunaan Antiseptik Dan Penggunaan Pembalut Dengan Kejadian Fluoralbus Pada Remaja Siswi SMA Negeri 8 Kendari Tahun 2017. (Jurnal Ilmiah Mahasiswa Kesehatan Masyarakat), 2(6).

Santrock, J. W. (2003). Adolescence: perkembangan remaja.

Sari, F.E. (2015). Dinamika Perkembangan Remaja. TIM, Jakarta.

Tesser, A. (1978). Self-generated attitude change. In Advances in experimental social psychology (Vol. 11, pp. 289338). Academic Press. https://doi.org/10.1016/S0065-2601(08)60010-6

Van Gog, T., \& Scheiter, K. (2010). Eye tracking as a tool to study and enhance multimedia learning. Learning and instruction, 20(2), 95-99. https://doi.org/10.1016/j.learninstruc.2009.02.009

Zhang, D., Zhou, L., Briggs, R. O., \& Nunamaker Jr, J. F. (2006). Instructional video in e-learning: Assessing the impact of interactive video on learning effectiveness. Information \& management, 43(1), 15-27. https://doi.org/10.1016/j.im.2005.01.004

Zhang, M., Zhou, M., Tang, F., Wang, Y., Nie, H., Zhang, L., \& You, G. (2020). Knowledge, attitude, and practice regarding COVID-19 among healthcare workers in Henan, China. Journal of Hospital Infection, 105(2), 183-187. https://doi.org/10.1016/j.jhin.2020.04.012 